\title{
UTILIZAÇÃO DA TÉCNICA DA ESPECTROFOTOMETRIA DE REFLECTÂNCIA NO INFRAVERMELHO PROXIMAL NA PREDIÇÃO DA COMPOSIÇÃO QUIIMICA DE UMA PASTAGEM CONSORCIADA ENTRE GRAMÍNEA + LEGUMINOSAS.
}

\section{UTILIZATION OF THE NEAR INFRARED REFLECTANCE SPECTRUM TECHNIQUE TO PREDICT THE CHEMICAL COMPOSITION OF GRASS AND LEGUMES MIXED FORAGE}

\author{
Rodrigo Távora MIRA \\ Orientador: Professor Titular José Sidney FLEMMING \\ Departamento de Zootecnia - UFPR
}

\begin{abstract}
RESUMO
A técnica da espectrofotometria de reflectância no infravermelho proximal (NIRS) tem demostrado ser uma técnica apta para predizer o valor nutritivo das forragens. Com o objetivo de avaliar o sistema de análise por infravermelho na predicação da MS, PB, FDA, FDN, Ca e P foi conduzido um experimento na região do Município de Guarapuava, Paraná - Brasil. Foram utilizadas 360 amostras em 6 cortes com intervalo entre cortes de $61,60,57,143$ e 103 dias, e uma altura de corte de $5 \mathrm{~cm}$ durante o período de 1 ano. As amostras são compostas de Lolium multiflorum, Trifolium repens, Trifolium pratense, Trifolum vesiculosum, e Lotus corniculatus no inverno e pasto nativo no verão. As amostras foram secas em estufa com ar forçado a

$60^{\circ} \mathrm{C}$ e moídas em moinho Willey em peneira de $1 \mathrm{~mm}$. O espectro de absorção das amostras foi obtido através de um aparelho NR $4500 \mathrm{com}$ monocromador na NIRSystems e o sinal foi digitalizado e gravado na forma de $\log (1 / \mathrm{R})$. Foram selecionadas para calibração um total de 27, 31, 30, 29, 29, 29 amostras e, após feita a calibração, os coeficientes de regressão $\left(R^{2}\right)$ para as frações MS, PB, FDA, FDN, Ca e $\mathrm{P}$ foram respectivamente: 0,$92 ; 0,92 ; 093 ; 0,97 ; 0,49 ; 0,64$ e um erro padrão de calibração de respectivamente 1,$67 ; 0,58 ; 1,52 ; 1,15$; 0,$10 ; 0,03$. Com base nos valores acima descritos se conclui que com a utilização do NIRS pode-se predizer de forma aceitável o valor nutritivo das forragens descritas neste experimento.
\end{abstract}

\section{ABSTRACT}

The Near Infrared Spectroscopy (NIRS) technique has been shown to be adequate to predict forage's nutrient content. With the goal to evaluate the analysis system base on NIRS on the prediction of DM (Dry Matter ), CP (Crude Protein), ADF (Acid Detergent Fiber, NDF (Neutral Detergent Fiber), $\mathrm{Ca}$, and $\mathrm{P}$ it was conducted a trial on Guarapuava County, Paraná State, Brazil. In this study 360 samples divided on 6 cuttings have been utilized, with intervals between cuttings of $61,60,57,143$, and 103 days, and cutting's height of $5 \mathrm{~cm}$ during a one year period. The samples were consisted of Lolium multiflorum, Trifolium repens, Trifolium pratense, and Lotus corniculatus on the winter, and native pasture on the summer. The samples were dried using a force- air convection oven at $65^{\circ} \mathrm{C}$, and they were grinded in Willey grinder with $1.0 \mathrm{~mm}$ screen. The absorption spectra was obtained using a NR4500 monochromator instrument from NIRSystems, and the measurements were transformed into log of inverse reflectance $(\log (1 / R))$. For the purpose of calibration, the regression coefficients $\left(R^{2}\right)$ for $D M, C P, A D F, N D F, C a$, and $P$ were, respectively: $0.92,0.92,0.93,0.97,0.49$, and 0.64 , while the calibration's standard error were, respectively: $1.67,0.58$, $1.52,1.15,0.10$, and 0.03 . Based on the results of this experiment it was concluded that NIRS analysis can predict nutrient quality of the forages selected on this trial. 